\title{
Occurrence of an unusual branchial mycoplasma-like infection in cockle Cerastoderma edule (Mollusca, Bivalvia)
}

\author{
Carlos Azevedo
}

Department of Cell Biology, Institute of Biomedical Sciences, and IMAR - Institute of Marine Research, University of Oporto, Lg. A. Salazar no. 2, P-4000 Porto, Portugal

\begin{abstract}
Unusual cytoplasmic structures were observed and described in gill epithelial cells during an occurrence of high mortality of cockle Cerastoderma edule obtained from an estuarine region of central Portugal (Aveiro) in 1991 and 1992. Ultrastructural studies on gaping cockles revealed a gill infection characterized by the presence of numerous long rod-shaped structures (RSS) regularly distributed, singly or in groups, within the cytoplasmic cisternae of gill epithelial cells. The RSS of 0.5 to $4 \mu \mathrm{m}$ length and a uniform width of $0.9 \mu \mathrm{m}$ presented a well organized structure in the basal portion of the host cell. Each RSS showed a homogeneous and electron-dense material delimited by a tri-laminar membrane devoid of cell wall. Lysed ultrastructural aspects of the host cell were observed. Due to their ultrastructural organization these RSS were identified as mycoplasma-like microorganisms and their pathogenic activity in the mortality of the cockle is discussed.
\end{abstract}

\section{INTRODUCTION}

Parasitic and symbiotic species of prokaryotic microorganisms have been reported in a range of marine animals (reviews by Tully \& Whitcomb 1979, Lauckner 1983, Sparks 1985). Amongst them, the mycoplasmas and mycoplasma-like organisms present a great variety of morphology. They are Gram-negative species accurring frequently in a number of different kinds of bivalves (Razin 1982) and in other marine invertebrates (Zimmer \& Woollacott 1983)

Recently, some mycoplasma-like microorganisms and other prokaryotic agents were described associated with mortalities of different bivalves (Azevedo \& Villalba 1991). The purpose of this work is to document the ultrastructural description of an unusual prokaryotic pathogenic microorganism, that appears to be a mycoplasma-like parasite of the cockle.

\section{MATERIAL AND METHODS}

Numerous gaping specimens of cockle Cerastoderma edule (Mollusca, Bivalvia) were collected during the summer of 1991 and 1992 from an estuarine region of central Portugal (Aveiro).

Small living fragments of the gills were firstly observed by light microscopy (LM). For transmission electron microscopy (TEM) small fragments of the infected gills were fixed in $3.0 \%$ glutaraldehyde in $0.2 \mathrm{M}$ sodium cacodylate buffer $\mathrm{pH} 7.8$, for $3 \mathrm{~h}$ at $4{ }^{\circ} \mathrm{C}$, washed in the same buffer for $4 \mathrm{~h}$ at $4{ }^{\circ} \mathrm{C}$, and post-fixed in buffered $2 \% \mathrm{OsO}_{4}$ for $2 \mathrm{~h}$ at the same temperature. Some fragments were fixed only in buffered glutaraldehyde under the same conditions. After dehydration in an ethanol series, the infested gills were embedded in Epon, sectioned, double stained with uranyl acetate and lead citrate, and observed in a JEOL 100CXII TEM operated at $60 \mathrm{kV}$.

For experimental infections, some normal living cockles were placed in an aerated aquarium among several gaping cockles for $15 \mathrm{~d}$. During this period some gaping cockles died but were maintained in the aquarium for $2 \mathrm{~d}$ after death. The normal samples were later submitted to laboratory techniques for diagnostic studies. 


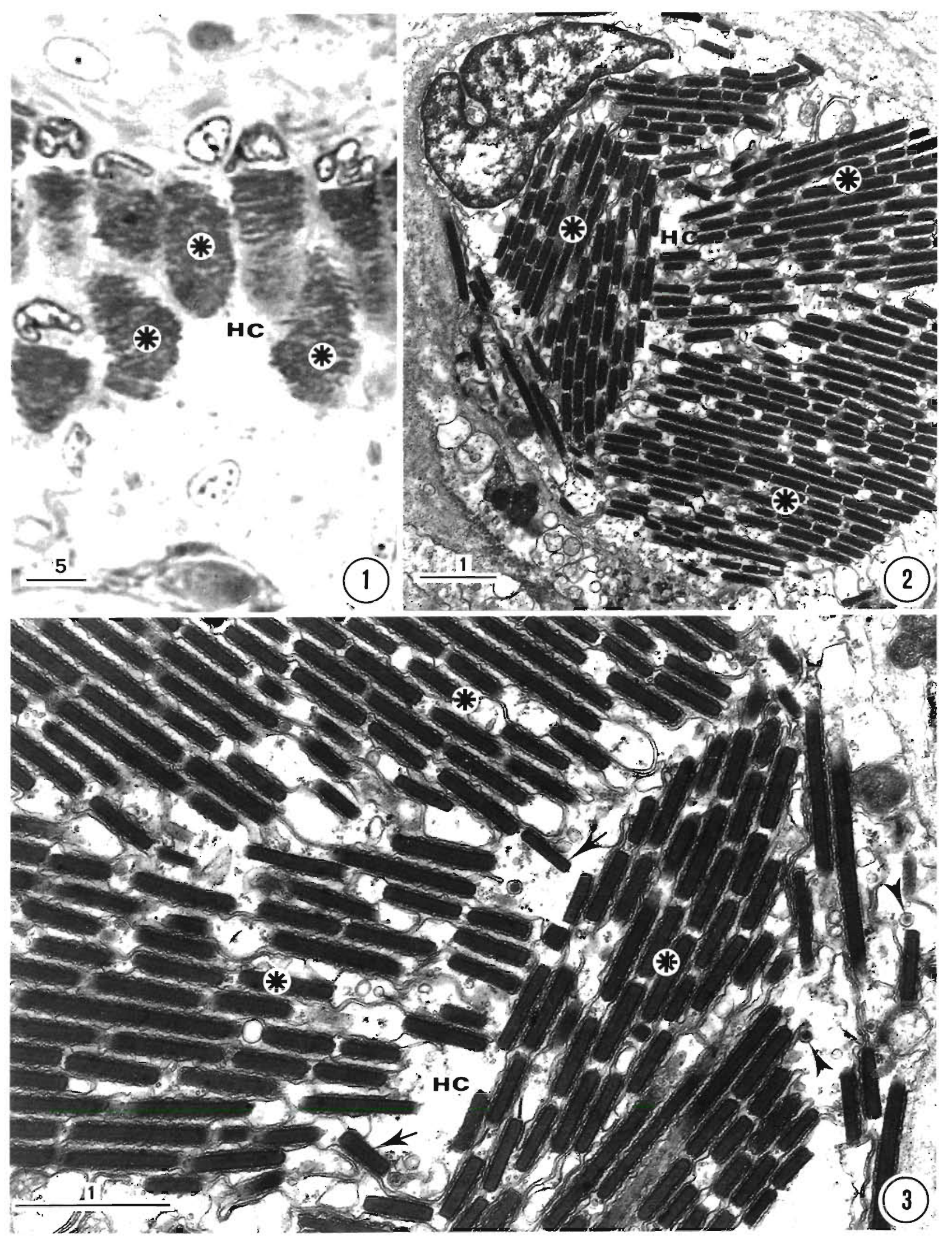

Figs. 1 to 3. LM and TEM aspect of the rod-shaped structures observed in the host gill of cockle Cerastoderma edule. Scale bars in $\mu \mathrm{m}$. Fig. 1. Light micrograph of a semithin section through the gill epithelium showing numerous rod-shaped structures (mycoplasma-like organisms) (*) within host cell cytoplasm (HC). Fig. 2. Ultrathin section through some host cells (HC) showing some ultrastructural aspects of the different sections of the mycoplasma-like organisms (*). Fig. 3. Ultrathin transverse section of several mycoplasma-like organisms (*) contained within compressed vacuoles with evident membrane (double arrows) within the host cell cytoplasm (HC). Note some free mycoplasma-like organisms (arrows), present in the cytoplasm of the host cells 


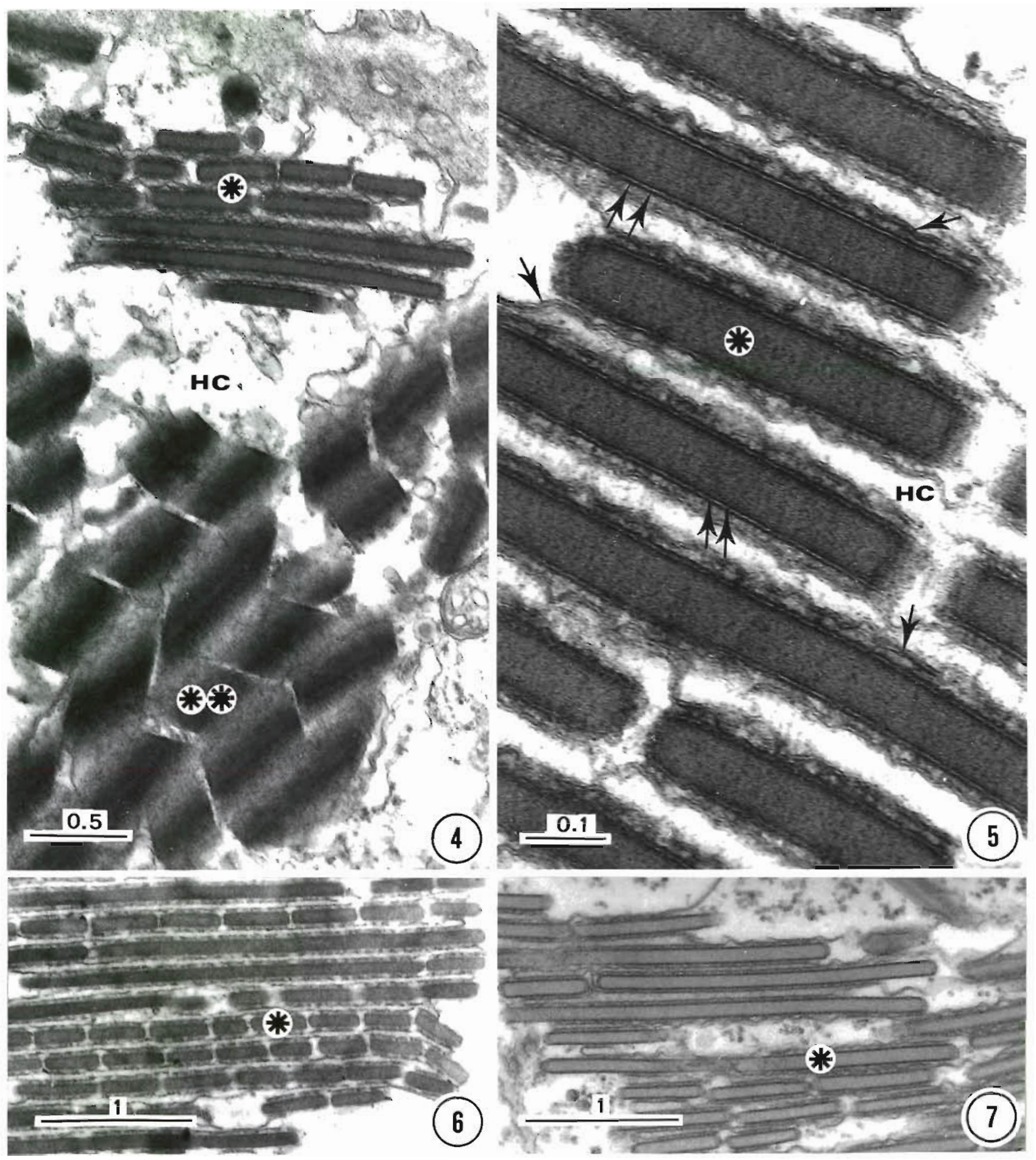

Figs. 4 to 7. Ultrastructural aspects of the rod-shaped structures observed in the host gill of cockle Cerastoderma edule. Scale bars in $\mu \mathrm{m}$. Fig. 4. Ultrathin section of a host cell through the mycoplasma-like organisms showing transverse (*) and oblique sections (**). Fig. 5. Detail of a transverse section of the mycoplasma-like organisms showing the vacuole membranes (arrows), the tri-laminar plasmalemma of the mycoplasma-like organisms (double arrows) and its electron-dense matrix (*). The hyaloplasm of the host cell (HC) seems devoid of organelles. Fig. 6. Ultrathin section of the mycoplasma-like organisms (*) fixed only with buffered glutaraldehyde. Fig. 7. Ultrathin section of the mycoplasma-like organisms (*) observed without contrast 


\section{RESULTS}

Unusual cytoplasmic structures in the branchial epithelium of gaping cockles were observed under a light microscope (Fig. 1). Observed by TEM, they were numerous rod-shaped structures (RSS) presenting a well organized array at the basal portion of the host cells, apparently lysed and showing some light cytoplasmic areas at the periphery of the host cells (Fig. 2). In some serial ultrathin sections it was possible to count thousands of RSS per cell, and hundreds on the same section, presenting well arranged layers (Figs. $2 \& 3$ ). The RSS show homogeneous and electron-dense material delimited by a tri-laminar membrane of about $90 \AA$ thickness $(2$ dense layers separated by a pale layer) (Fig. 5). They have some characteristics of Gram-negative prokaryote, however, the typical structures, such as fibrillar DNA or ribosomes, were not apparent and they were devoid of an evident external cell wall (Figs. 4 \& 5).

The individual RSS measured about $0.9 \mu \mathrm{m}$ wide and when sectioned longitudinally were of varying lengths, some as long as $4 \mu \mathrm{m}$ (Fig. 3).

Normal cells without RSS were observed next to cells containing these structures. Infected host cells contained pycnotic nuclei, sometimes with a nucleolus containing a great quantity of fibrillar component and few granular component. The host cell cytoplasm exhibited evidence of lysis, mainly the presence of electron-lucent areas, numerous vacuoles, few mitochondria and absence of ribosomes. Most of these vacuoles contained RSS that appeared to be free within the host-cell vacuoles. Ultrastructural data revealed that the RSS, singly or in groups, were contained in membrane-lined vacuoles in well organized stratified layers (Figs. 2 to 5). The membrane of the compressed vacuoles was also seen either in glutaraldehyde-fixed material (Fig. 6) or without contrast (Fig. 7). Some aspects of binary and multiple fission were observed in ultrathin serial sections (Figs. $2 \& 3$ ).

The RSS obtained from the epithelium gill cells fixed only with buffered glutaraldehyde appear less dense (Fig. 6). Similar contrast was observed in unstained ultrathin sections (Fig. 5).

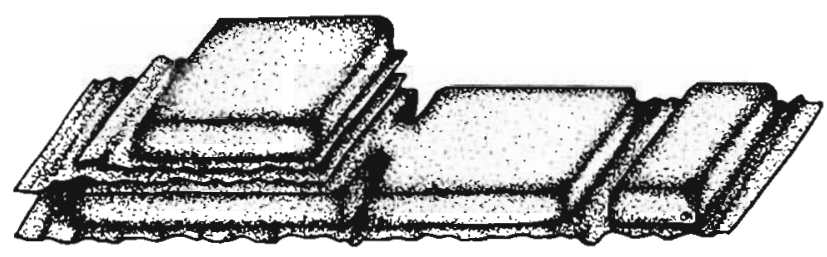

Fig. 8. Semischematic drawing summarizing the ultrastructure of the rod-shaped structures (mycoplasma-like organisms) as described in the text and illustrated in electron micrographs
In advanced lytic activity, complete disintegration, consequent disappearance of the vacuolar membranes and liberation of the RSS were sometimes observed in host cytoplasm (Fig. 3).

The 3-dimensional structure of the RSS is shown in Fig. 8 that was obtained by observation from ultrathin serial sections.

Most of the gaping cockles (ca 65 to $73 \%$ ) examined under LM were infected with the RSS described here. Experimental infections with living cockles were attempted without success.

\section{DISCUSSION}

Mycoplasma-like RSS were found in most gaping specimens, and less frequently in living cockles, after the highest mortality observed in 1991 and 1992. This mortality occurred only during the summer when the temperature was higher

Signs associated with RSS infection may represent the response to environmental factors, as hypothesized in relation to other parasites (Elston \& Peacock 1984, Elston 1986). Among these factors, temperature is possibly the most important facilitating transmission of host susceptibility.

The ultrastructural characteristics observed in ultrathin sections of our RSS strongly suggested that they were prokaryotic microorganisms. This appears to be the first report of these unusual and hitherto unknown microorganisms. The lack of cell wall, the Gram-negative characteristics and morphology suggests that the RSS were similar to the mycoplasmas, and we refer to the RSS as mycoplasma-like organisms. Mycoplasmas are well known from several marine species, mainly in bivalve and other animal species (Harshbarger et al. 1977, Zimmer \& Woollacott 1983, Sparks 1985). A survey of the literature confirms that the ultrastructure of the RSS had the same basic morphology as previously described mycoplasmas (Anderson et al. 1965).

These mycoplasma-like organisms may be responsible for the Portuguese cockle mortalities of the last years. Further studies are in progress in order to attempt their isolation and culture, and consequently, determine the level of their pathogenicity and transmissibility of the RSS.

Although mycoplasma-like organisms cause disease in a wide array of hosts their taxonomic interrelationships seem yet to be an enigma. This study being the first record, experimental infections are needed to confirm this suggestion.

Acknowledgements. This work was partially supported by 'CME-JNICT' and the A. Almeida Foundation. 


\section{LITERATURE CITED}

Anderson, D. R., Hopps, H. E., Barile, M. F., Bernheim, B. C. (1965). Comparision of the ultrastructure of several Rickettsiae, ornithosis virus, and mycoplasma in tissue culture. J. Bacteriol. 90: 1387-1404

Azevedo, C., Villalba, A.(1991). Extracellular giant Rickettsiae associated with bacteria in the gill of Crassostrea gigas (Mollusca, Bivalvia). J. Invertebr. Pathol. 58: 75-81

Elston, R. A. (1986). Occurrence of branchial rickettsiales-like infections in two bivalve molluscs. Tapes japonica and Patinopecten yessoensis, with comments on their significance. J. Fish Dis. 9: 69-71

Elston, R. A., Peacock, M. G. (1984). A rickettsiales-like infection in the Pacific razor clam, Siliqua patula. J. Invertebr. Pathol. 44: 84-96

Harshbarger, J. C., Chang, S. C., Otto, S. V. (1977).

Responsible Subject Editor: A. K. Sparks, Seattle, Washington, USA
Chlamydiae (with phages), mycoplasmas, and Rickettsiae in Chesapeake Bay bivalves. Science 196: 666-668

Lauckner, G. (1983). Diseases of Mollusca: Bivalvia. In: Kinne, O. (ed.) Diseases of marine animals, Vol. II, Chap. 13. Biologische Anstalt Helgoland, Hamburg, p. 477-961

Razin, S. (1982). Mycoplasmas. In: Parker, S. P. (ed.) Synopsis and classification of living organisms. McGraw-Hill Book Company, New York, p. 42-43

Sparks, A. K. (1985). Rickettsiae, Clamydiae, and mycoplasms of invertebrates: In: Sparks, A. K. (ed.) Synopsis of invertebrate pathology. Elsevier, Amsterdam, p. 165-180

Tully, J. G., Whitcomb, R. F. (1979). Human and animal mycoplasmas. In: Tully, J. G., Whitcomb, R. F. (eds.) The mycoplasmas, Vol. II. Acad. Press, New York

Zimmer, R. L., Woollacott, R. M. (1983). Mycoplasma-like organisms: occurrence with the larvae and adults of a marine bryozoan. Science 220: 208-210

Manuscript first received: September 28, 1992

Revised version accepted: March 4, 1993 